\title{
PLANT REGENERATION THROUGH MULTIPLE SHOOT FORMATION IN BLACKGRAM
}

\author{
S. K. Roy, M. S. Haque and M. K. Siddiqua ${ }^{1}$ \\ Department of Biotechnology, Bangladesh Agricultural University \\ Mymensingh-2202, Bangladesh
}

\begin{abstract}
Blackgram (Vigna mungo L. Hepper, syn. Phaseolus mungo L.) is one of the four major pulse crops. So far, no reports of tissue culture studies aiming at genetic improvement of this crop are available in Bangladesh. The present study comprised of experiments for direct shoot regeneration and plantlet formation in blackgram. Shoot tip explants were cultured on different concentrations of BAP (1.0, 5.0 and $\left.10.0 \mathrm{mg} \mathrm{L}^{-1}\right)$ and Kinetin (1.0, 5.0 and 10.0 $\left.\mathrm{mg} \mathrm{L}^{-1}\right)$. The highest percentage $(85.00 \%)$ of multiple shoot initiation was observed in the MS medium supplemented with $5.0 \mathrm{mg} \mathrm{L}^{-1}$ kinetin. The regenerated shoots were transferred to rooting medium supplemented with different concentrations of NAA. A high frequency of $85 \%$ rooting was observed with $0.2 \mathrm{mg} \mathrm{L}^{-1} \mathrm{NAA}$. The rooted plants were transferred to pots for hardening.
\end{abstract}

Key Words : Blackgram, Multiple shoot, Regeneration, Shoot tip culture

\section{INTRODUCTION}

Blackgram (Vigna mungo L. Hepper, syn. Phaseolus mungo L.) is one of the most important pulse crops grown widely in the North/North-Western side of Bangladesh (BARI, 1998). It is mainly a day neutral warm season crop commonly grown in semi-arid to sub-humid low land tropics and sub-tropics. Of the total legume crops, $10.5 \%$ production comes from blackgram. Pulses, the protein rich agricultural crops, play an important role in human nutrition. They are the cheapest source of protein for the poor and are called the poor men's meat (Mian, 1976). In addition to protein, pulses contain a remarkable amount of minerals, vitamins and carbohydrates. Among the various pulses, blackgram ranks second in respect of yield and production of seed protein.

It has been reported that the average yield of blackgram is about $1000 \mathrm{~kg} \mathrm{ha}^{-1}$ and the protein content is $25-26 \%$ (BINA, 2004). It contains sulphur containing amino acids, methionine and cysteine and also contains lycine which are excellent component of balanced human nutrition. Blackgram is one of the cheapest sources of plant protein for the people of Bangladesh. It has been used as food providing major source of protein in cereal based diet. In spite of its multi purpose uses, its cultivation is decreasing day by day both in acreage and yield (BBS, 2006). Annual import of pulses in Bangladesh is

${ }^{1}$ Department of Horticulture, Bangladesh Agricultural University, Mymensingh-2202, Bangladesh 
about 36 thousand tons (BBS, 2005) for which we have to spend a lot of foreign currency every year.

The application of classical methods of breeding for both diseases and pest resistance has resulted in only limited success due to the long generation time. But, the integration of genetic engineering into breeding programs may provide powerful tools to overcome these limitations by introducing specific genetic changes that can be utilized for blackgram improvement within a short period of time.

Plant biotechnology is mainly rooted on plant cell culture. Regeneration of plant from cell or tissue is an important and essential compound of biotechnology, which is required for the genetic manipulation of plants. Plant cell culture has become an excellent method for plant cell differentiation as well as a supplementary technique for plant breeding programs through the uses of new and expanded genetic variability (Nakamura and Maeda, 1989). To get disease free healthy plant materials, it is very urgent to develop a protocol for in vitro propagation of blackgram. In spite of plenty of information on tissue culture studies elsewhere in the world, no reports of studies are available in Bangladesh. To achieve this goal we need to look for suitable germplasms followed by developing varieties as well as rapid multiplication through tissue culture. Considering the above facts, this study was undertaken to determine the optimum concentrations of growth regulators for in vitro callus induction, to sort out suitable explant for regeneration, and to develop a protocol of plantlet regeneration.

\section{MATERIALS AND METHODS}

Seeds of the variety BINA Mash-1 were collected from Bangladesh Institute of Nuclear Agriculture. Surface sterilization of mature seeds was carried out under Laminar Air Flow Cabinet. Seeds were washed by sterile distilled water for 3 to 5 minutes. Later, they were rinsed in $70 \%$ ethyl alcohol followed by washing with sterile distilled water for 3 times. Finally, surface disinfection was done with $0.1 \% \mathrm{HgCl}_{2}$ for five minutes with continuous agitation. The seeds were then washed 5 times with sterile distilled water to remove the sterilant. The mature seeds were placed on a solidified agar medium for germination in sterile vials. Later the vials were wrapped with Para film. Seven to ten days after germination, shoot tips of seedlings were dissected and cultured on MS medium supplemented with with three levels of $\operatorname{BAP}(0,5,10 \mathrm{mg} / \mathrm{l})$ and three levels of Kinetin $(0,5,10 \mathrm{mg} / \mathrm{l})$ for direct regeneration. For successful rooting, 3-4 $\mathrm{cm}$ usable shoots excised from multiple shoots were implanted to rooting medium consisting of MS medium supplemented with IBA $\left(2 \mathrm{mg} \mathrm{L}^{-1}\right)$, IAA $\left(5 \mathrm{mg} \mathrm{L}^{-1}\right)$ and NAA $\left(0.2 \mathrm{mg} \mathrm{L}^{-1}\right)$.

MS (Murashige and Skoog, 1962) medium supplemented with different concentrations and combinations of phytohormones as per treatments was used for shoot induction, shoot multiplication and rooting of shoots. Hormones were added separately to different media according to their requirements. For the preparation of media, stock solutions were prepared at the beginning and stored at $4 \pm 1^{\circ} \mathrm{C}$ temperature. The respective media were prepared from the stock solutions. $\mathrm{pH}$ of the media was adjusted to 5.8 and then 
agar @ $9.0 \mathrm{~g}$ was added to solidify the medium. The medium was then gently heated without boiling with continuous stirring till complete dissolution of agar. Required volume of hot medium was dispensed into culture vessels or conical flasks. After dispensing the medium the culture vessels were plugged with cork and marked with different codes with the help of glass marker to indicate specific hormonal combination. To ensure aseptic condition under in vitro, all instruments, glass wares and culture media were sterilized by autoclaving at $1.16 \mathrm{~kg} / \mathrm{cm}^{2}$ pressure at $121^{\circ} \mathrm{C}$ for 30 minutes. The culture vials were transferred to growth room and were allowed to grow in controlled environment. The temperature of the growth room was maintained with in $25 \pm 2^{\circ} \mathrm{C}$ by an air conditioner. A 16 hours light period was maintained with light intensity of 2000 lux. One month old adequately rooted shoots when reached a height of $4-5 \mathrm{~cm}$ were brought out from culture room and kept in room temperature for 7 days. Plantlets were then taken out from vial and agar was washed out gently from roots. These plantlets were transplanted in small pots contained compost, soil and sand $(1: 2: 1)$ and were covered with transparent sheets. They were nurtured under room temperature in presence of sufficient light. An average days nursing under room condition enabled them to adapt in outdoor conditions. In that conditions the plantlet were watered every alternate day.

The data for the parameters recorded in the present study were statistically analyzed by the programmed MSTATC and Microsoft Excel wherever applicable. The experiment was arranged in Completely Randomized Design (CRD). The analysis of variances for different parameters was performed and the means were compared by Duncan's Multiple Range Test (DMRT).

\section{RESULTS AND DISCUSSION}

In vitro plant regeneration capability BINA Mash-1 cultivar of blackgram was studied using shoot tips as explants. Shoot tip explants were cultured on different concentrations of BAP and Kinetin for shoot proliferation. The percentage of shoot initiation was significantly influenced by the concentration of the growth regulators used in the experiment. The highest shoot proliferation (85.0\%) was observed with the supplementation of $5.0 \mathrm{mg} \mathrm{L}^{-1}$ Kinetin and the lowest shoot proliferation $(17.5 \%)$ was observed in the addition of $10.0 \mathrm{mg} \mathrm{L}^{-1} \mathrm{BAP}$ to the medium (Table 1).

Cultured explants were carefully observed in regular basis for data collection on days required for shoot regeneration. The growth regulators significantly affected the days required for shoot initiation. Table 1 shows that $5.0 \mathrm{mg} \mathrm{L}^{-1}$ Kinetin performed better and needed least number of days (14.75) for shoot regeneration which was statistically similar to that in $10.0 \mathrm{mg} \mathrm{L}^{-1}$ Kinetin. Maximum number of days 18.25 was required in $1.0 \mathrm{mg} \mathrm{L}^{-1}$ BAP.

The number of shoots produced per explant varied with different concentrations of hormones (Kinetin and BAP) (Table 1). The concentration of $5.0 \mathrm{mg} \mathrm{L}^{-1}$ Kinetin showed the highest (8.50) number of shoots per explant (Fig. 1B) followed by $10.0 \mathrm{mg} \mathrm{L}^{-1}$ Kinetin 
(Fig. 1C) and the lowest number (1.75) of shoots per explant was observed in $10.0 \mathrm{mg} \mathrm{L}^{-1}$ BAP (Table 1, Fig. 1A). Similar shooting frequency was also reported by Geeta et al. (1998).

Table 1. Effect of different concentrations BAP and NAA on shoot induction

\begin{tabular}{c|c|c|c|c|c|c}
\hline Hormone & $\begin{array}{c}\text { Concentrations } \\
\text { (mg L-1 })\end{array}$ & $\begin{array}{c}\text { Percentage of } \\
\text { explant } \\
\text { induced shoot }\end{array}$ & $\begin{array}{c}\text { Days required } \\
\text { for shoot } \\
\text { initiation }\end{array}$ & $\begin{array}{c}\text { Number of } \\
\text { shoot } \\
\text { /explant }\end{array}$ & $\begin{array}{c}\text { Number of } \\
\text { leaves } \\
\text { plantlet }^{-1}\end{array}$ & $\begin{array}{c}\text { Length of } \\
\text { shoot } \\
(\mathrm{cm})\end{array}$ \\
\hline BAP & 1.0 & $27.50 \mathrm{~d}$ & $18.25 \mathrm{a}$ & $2.75 \mathrm{~d}$ & $2.00 \mathrm{~d}$ & $2.25 \mathrm{c}$ \\
& 5.0 & $20.00 \mathrm{e}$ & $18.00 \mathrm{a}$ & $2.00 \mathrm{e}$ & $1.50 \mathrm{e}$ & $2.15 \mathrm{c}$ \\
Kinetin & 10.0 & $17.50 \mathrm{e}$ & $17.25 \mathrm{ab}$ & $1.75 \mathrm{e}$ & $1.00 \mathrm{f}$ & $1.92 \mathrm{~d}$ \\
& 1.0 & $57.50 \mathrm{c}$ & $16.00 \mathrm{bc}$ & $5.75 \mathrm{c}$ & $3.00 \mathrm{c}$ & $2.65 \mathrm{~b}$ \\
& 5.0 & $85.00 \mathrm{a}$ & $14.75 \mathrm{c}$ & $8.50 \mathrm{a}$ & $6.00 \mathrm{a}$ & $3.85 \mathrm{a}$ \\
\hline $\mathrm{CV}(\%)$ & 10.0 & $77.50 \mathrm{~b}$ & $14.75 \mathrm{c}$ & $7.75 \mathrm{c}$ & $5.00 \mathrm{~b}$ & $3.75 \mathrm{a}$ \\
\hline $\operatorname{LSD}_{(0.05)}$ & & 9.67 & 6.76 & 9.67 & 7.64 & 5.00 \\
\hline
\end{tabular}

Note : Means having common letter(s) are statistically identical at $5 \%$ level of probability

The number of leaves per explant was significantly influenced by growth regulators used in the experiment. The concentration of $5.0 \mathrm{mg} \mathrm{L}^{-1}$ Kinetin showed the highest number of leaves per explant (6.0) and the lowest number of leaves per explant was observed in the concentration of $10.0 \mathrm{mg} \mathrm{L}^{-1} \mathrm{BAP}$ (Table 1).

The length of shoots was also significantly influenced by growth regulators used in the experiment. The concentration of $5.0 \mathrm{mg} \mathrm{L}^{-1}$ Kinetin showed the longest shoots $(3.85 \mathrm{~cm})$ which was statistically similar to that in the concentration of $10.0 \mathrm{mg} \mathrm{L}^{-1}$ Kinetin and the shortest shoot $(1.92 \mathrm{~cm})$ was observed in the concentration of $10.0 \mathrm{mg} \mathrm{L}^{-1} \mathrm{BAP}$ (Table 1).

After considering all the above parameters, it was clear that shoot tip explant responded spontaneously for shoot induction and among the different concentrations of BAP and kinetin, $5.0 \mathrm{mg} \mathrm{L}^{-1}$ kinetin performed better than any other treatments. Geeta et al. (1998) reported that MS medium supplemented with BAP at $3.0 \mathrm{mg} \mathrm{L}^{-1}$ in combination with NAA at $1.5 \mathrm{mg} \mathrm{L}^{-1}$ performed better for shoot differentiation. However, we found good shoot proliferation with either of Kinetin or BAP.

The regenerated shoots were collected subcultured on MS medium supplemented with $2.0 \mathrm{mg} \mathrm{L}^{-1} \mathrm{IBA}, 5.0 \mathrm{mg} \mathrm{L}^{-1} \mathrm{IAA}, 0.2 \mathrm{mg} \mathrm{L}^{-1} \mathrm{NAA}$ and hormone free medium in order to allow root formation. Root development varied with IBA, IAA, NAA and growth regulator free medium. The rooting of shoots was significantly affected in terms of days required for root initiation. The concentration of $0.2 \mathrm{mg} \mathrm{L}^{-1} \mathrm{NAA}$ performed better and required least number of days (7.0) for rooting. Maximum days (10.0) were required for the growth regulator free medium (Table 2). 
Roy et al.

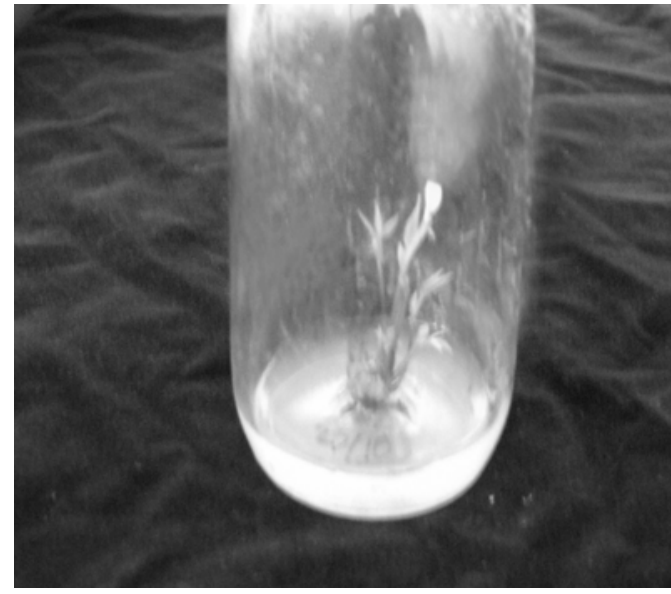

Fig. 1A

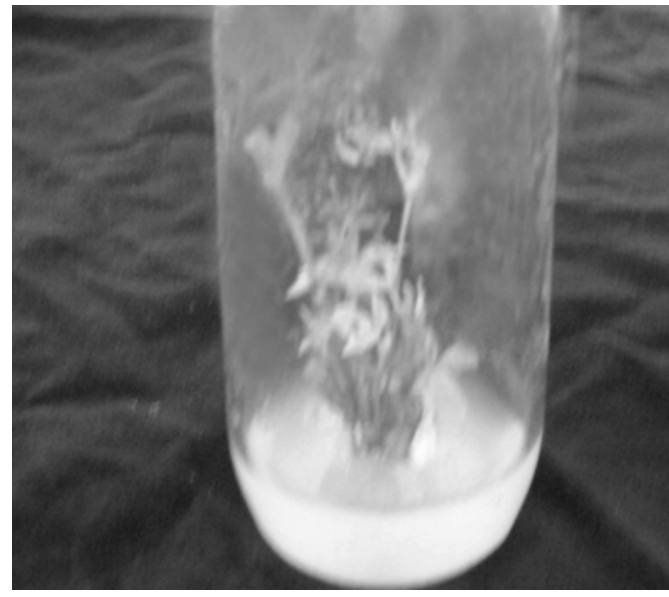

Fig. 1C

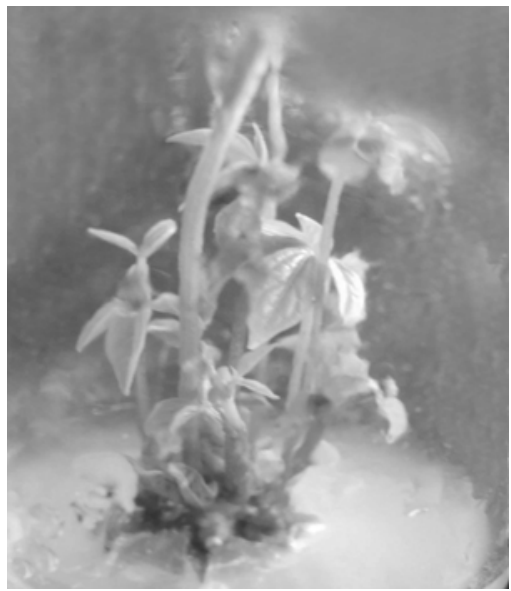

Fig. 1B

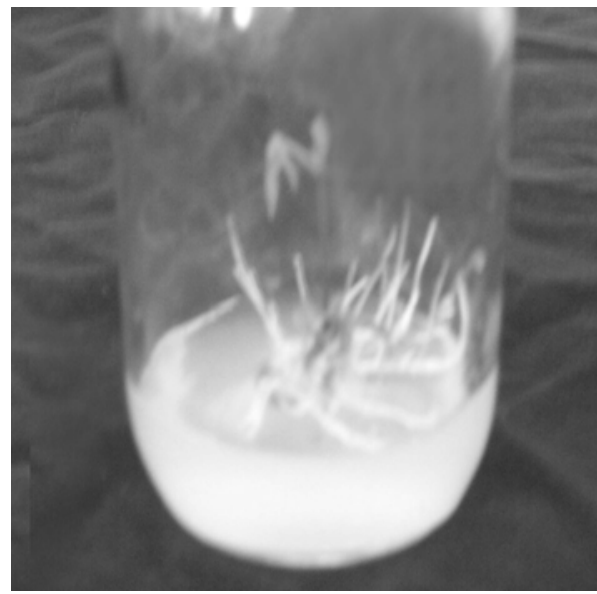

Fig. 1D

Fig. 1. Multiple shoots from the shoot tip explant of BINA Mash-1 in : A) MS medium supplemented with $10.0 \mathrm{mg} \mathrm{L}^{-1}$ BAP, B) MS medium supplemented with $5.0 \mathrm{mg} \mathrm{L}^{-1}$ Kinetin; C) in MS medium supplemented with $10.0 \mathrm{mg} \mathrm{L}^{-1}$ Kinetin, and D) Root formation from the regenerated shoots in MS medium supplemented with $0.2 \mathrm{mg} \mathrm{L}^{-1} \mathrm{NAA}$.

Table 2. Effect of different hormones on root induction

\begin{tabular}{l|cc|c}
\hline \multicolumn{1}{c|}{$\begin{array}{c}\text { Hormone concentrations } \\
\left(\mathrm{mg} \mathrm{L}^{-1}\right)\end{array}$} & $\begin{array}{c}\text { Days required for } \\
\text { root initiation }\end{array}$ & $\begin{array}{c}\text { Percentage of shoots } \\
\text { showing roots }\end{array}$ & Length of roots $(\mathrm{cm})$ \\
\hline MS medium without hormone & $10.00 \mathrm{a}$ & $20.00 \mathrm{c}$ & $2.00 \mathrm{~d}$ \\
$0.2 \mathrm{NAA}$ & $7.00 \mathrm{~d}$ & $80.00 \mathrm{a}$ & $6.12 \mathrm{a}$ \\
5.0 IAA & $8.00 \mathrm{c}$ & $75.00 \mathrm{a}$ & $4.60 \mathrm{~b}$ \\
2.0 IBA & $9.00 \mathrm{~b}$ & $40.00 \mathrm{~b}$ & $3.22 \mathrm{c}$ \\
\hline CV $(\%)$ & 6.42 & 9.30 & 9.61 \\
\hline LSD $_{(0.05)}$ & 0.80 & 7.53 & 0.60 \\
\hline
\end{tabular}

Note : Means having common letter(s) are statistically identical at $5 \%$ level of probability 
Rooting was achieved with all treatments and was remarkable in $0.2 \mathrm{mg} \mathrm{L}^{-1} \mathrm{NAA}$ (Fig. 1D). The highest percentage of rooting $(80.0 \%)$ was found with $0.2 \mathrm{mg} \mathrm{L}^{-1}$ NAA which was statistically similar to that in $5.0 \mathrm{mg} \mathrm{L}^{-1}$ IAA and the lowest percentage (20.0) of rooting was observed in the medium without hormone (Table 2). Raman and Jaiwal (2002) reported that efficient rooting $(100 \%)$ of the shoots was achieved on medium containing half MS salts, full MS vitamins and IBA $(2.5 \mu \mathrm{M})$. We found NAA more efficient than IBA in rooting of shoots.

The root elongation was also examined. It was observed that the concentration of $0.2 \mathrm{mg}$ $\mathrm{L}^{-1}$ NAA showed the highest elongation of roots $(6.12 \mathrm{~cm})$ and the shortest roots $(2.0 \mathrm{~cm})$ were observed in the growth regulator free medium (Table 2). It was clear from the above discussion that $0.2 \mathrm{mg} \mathrm{L}^{-1} \mathrm{NAA}$ was better than any other treatments for root formation. Das et al. (2002); Geeta et al. (1998) reported that IBA was the most effective for rooting of blackgram.

Healthy plantlets of 7-8 $\mathrm{cm}$ in height were planted in a mixture of garden soil, sand and cowdung at the ratio of $2: 1: 1$. Immediately after transplantation, the plants along with pots were kept in diffused sunlight in the controlled environment of the growth room. Survival rate of the transplanted plantlets was $80 \%$. A method of direct regeneration from shoot tips has been developed. However, further studies are necessary to regenerate plants via callus formation.

\section{REFERENCES}

BARI (Bangladesh Agricultural Research Institute), 1998. The pilot Project for Increasing Production of masur, blackgram and mungbean, Joydebpur, Gazipur. Pub. No. 15.

BBS (Bangladesh Bureau of Statistics), 2005. Statistical Year Book of Bangladesh. Statistics Division, Ministry of Planning, Government of the People's Republic of Bangladesh. Dhaka. p. 558.

BBS (Bangladesh Bureau of Statistics), 2006. Monthly Statistical Bulletin-Bangladesh. Planning Division, Ministry of Planning, Government of the People's Republic of Bangladesh. Dhaka. p. 558.

BINA (Bangladesh Institute of Nuclear Agriculture), 2004. High yielding variety of blackgram (BINA Mash-1), June 2004, P. O. Box No. 4, Mymensingh. p. 1.

Das, P. K., Roy, M. and Mandal, N. 2002. In vitro organogenesis from shoot tip in blackgram. Indian J. Genet. Plant Breed., 62(1) : 91-92.

Geeta, N., Venkatachalam, P. and Rao, G. R. 1998. In vitro plant regeneration from shoot tip culture of blackgram (Vigna mungo L. Hepper). J. Tropic. Agric., 36(1/2) : 6-11.

Mian, A. L. 1976. Grow more pulses to keep your pulse well, an Assay of Bangladesh pulses. Dept. of Agron, BAU, Mymensingh. pp. 11-15.

Murashige, T. and Skoog, T. 1962. A revised medium for rapid growth and bioassays with tobacco tissue cultures. Physiol. Plant., 15 : 473-497.

Nakamura, T. and Maeda, E. 1989. Scanning electron microscope study on Japonica type rice callus cultures with emphasis on plantlet initiation. Japan J. Crop. Sci., 58 : 395-403.

Raman, S. and Jaiwal, P. K. 2002. Age, position in mother seedling, orientation and polarity of the epicotyl segments of blackgram (Vigna mungo L. Hepper) determines its morphogenic response. Plant Sci., 163(1) : 101-109. 